\title{
The Use of Metallography in Archaeological Studies
}

G. Sperl*

* Univ.Prof. Dr.phil.Dr.mont.Dipl.-Ing.; Lecturer on Historical Materials at the Universities of Leoben, Innsbruck and Vienna: researcher at the Erich-Schmid Institut für Materialwissenschaft der Österreichischen Akademie der Wissenschaften, Leoben. Now since 2002: Institut für Historische Werkstoffe (IHW-EFDZ), Mareckkai 46, A-8700 Leoben (Austria) (sperl@unileoben.ac.at)

On the topic

The use of metals doesn't start with the invention of metallurgical work. Long before that, native metals like gold, silver and copper, also meteoric iron, were shaped by man into tools and jewelry. With the use of fire to melt and reduce the metals from the ore (pyrotechnology), the working places (smelting sites, foundries, smithies) can be found by their typical remains: beside the metal worked there are also always slags, with metal inclusions, furnace lining with adhering slag, tubes (tuyeres) for the concentrated combustion of the fuel (charcoal), and often also cinder and hammerscale are found. All these findings can be precisely characterized by metallographic methods, from microscopy, Xray-fluorescence and element-analyzing electron microscopes. Macroscopic criteria like specific weight or magnetic properties are often of special interest.

Some Highlights

The very first piece of copper molten in human context, was found in Catal Höyük, Turkey, from the 7th mill. BC, together wit hammered native copper and beads made of galena $(\mathrm{PbS})$, initially confused with metallic lead [1].

In the central European copper-age (4000-1800 BC) the most interesting piece of copper is the axe-blade (FIG.1) of the glacier-mummy form the Ötztaler Alps in Tyrol, commonly called "Ötzi", or "Frozen Fritz" from 3300 BC, which was researched in Leoben for the first time [2]. The axe-blades seen here are reconstructed (left) or examples from the same period, that can be reached by metallography. So the way and quality of making can be reconstructed

The technology of copper-smelting in the European bronze-age (1800-800 BC) had its culmination around $1000 \mathrm{BC}$ (urnfield time), using ore-roasting and slagging of iron by soft-reducing smelting. Its peculiarities can be found by archaeology and then by metallographic research on slags. [3].

The very first pioneers of ironmaking in Italy were the Etruscans, whose highly efficient metallurgy of about $600 \mathrm{BC}$ degraded in the Roman period after $200 \mathrm{BC}$. In the same period the iron production climbed to high levels of quality in the north of Italy, in Austria, Germany, Switzerland and France. The high qualitysteel FERRUM NORICUM from the province Noricum, now Carinthia and Styria in Austria, can be defined by the methods of modern metallography, where also the composition of the slag inclusions defines the origin of the metal [4]. 
Résumé

So scientific, especially metallographical research on archaeological or historical objects cannot be ignored anymore by the digging archeologists. Metallography is also useful for proving the authenticity of historical objects. Its precision and modern ease of use will give more information on the development of mankind since prehistoric times, concerning technical and social aspects [5].

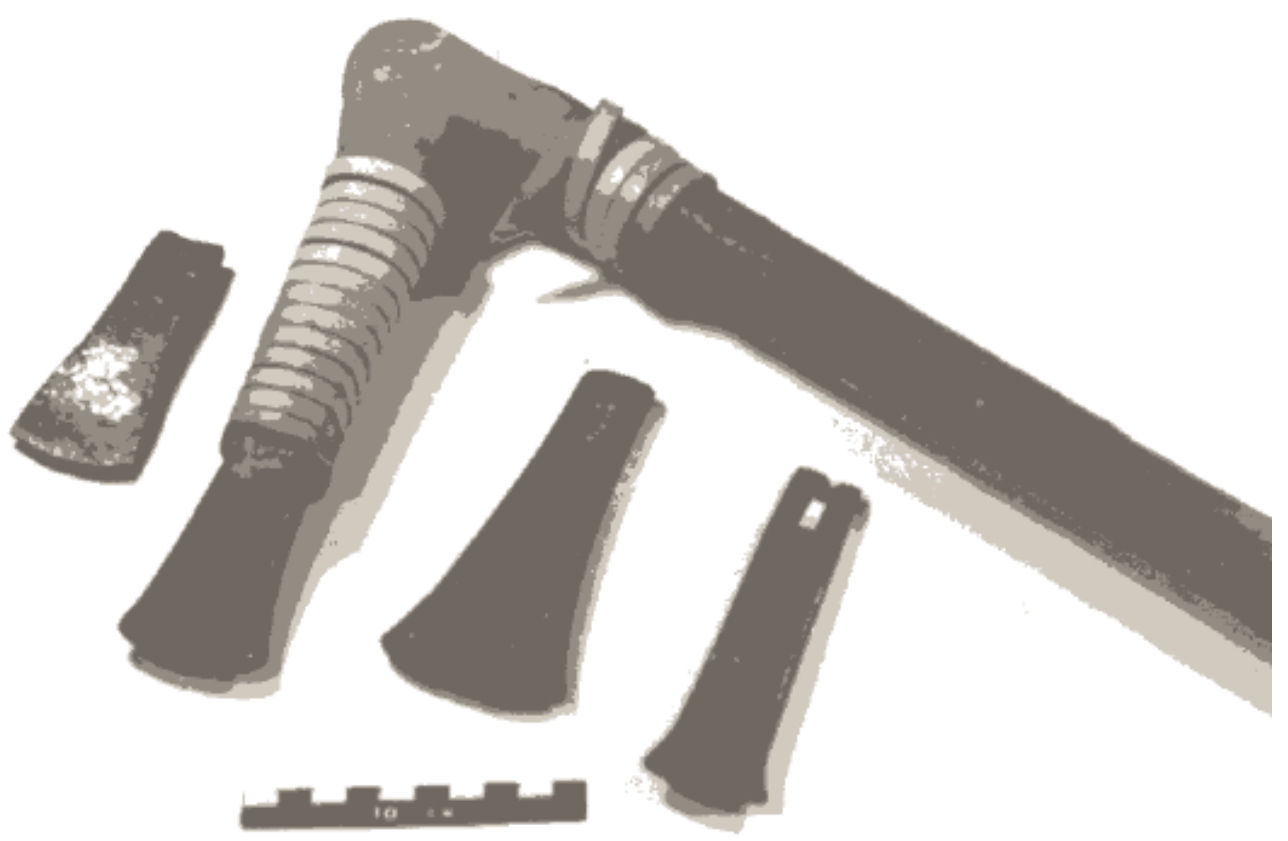

FIG.1. The axes of the copper-age, often of stone, rarely of copper, are mounted in a wooden handle, whose best example is the axe of the "Oetzi" from $3300 \mathrm{BC}$ in the Alps; here the reconstructed handle shows the way of mounting glued in with birch-tar and fixed by a band of leather..

\section{References:}

[1] G.Sperl, Zur Urgeschichte des Bleies; in: Zeitschrift für Metallkunde, 81, (1990), H.11, .799-801; in English under publication: On the Prehistory of Lead.

[2] G.Sperl, Das Beil vom Hauslabjoch; in: Der Mann im Eis, Band 1, Uni Innsbruck 1992, S. 454-461; The Copper-Age Axe-bade from the Alps

[3] G.Sperl, Metallurgie des urgeschichtlichen Kupferwesens im Alpenraum; in: BHM 133 (1988), H.11, S.495-498 (Metallurgy of Prehistoric Copper Making)

[4] G.Sperl, FERRUM NORICUM, Stand der Forschung über eine frühe Stahlqualität, in: BHM 174(2002) H.3, S.61-65 ( An Early Quality-Steel)

[5] G.Sperl, Metalle und Zeit, eine oft vergessene Problematik; in: Zeitschrift für Metallkunde 92(2001), H.1, S.3-8; (Time and Metals, a Forgotten Problem) 